\title{
希少な機能の提示による 新商品のアイデア発想支援システム†
}

\author{
西原 陽子 *・日比野 純也 $*$ ・福本 淳一 * ・ 山西 良典 $*$
}

\begin{abstract}
新商品は日々，世の中に発信されている。新商品の多くは，既存の商品の特徴の組合せにより作られて いると見なすことができる。しかし，既存の商品の特徴を組合わせれば，多くの人に購入される新商品と なるわけではない。商品には特徴があり，特徴を組み合せることにより，新しい特徴が得られる可能性が ある. 新しく得られる特徵が希少であれば，元の元となった商品の組合せは，多くの人に購入される新商 品の種になる可能性がある。本論文では, 新商品のアイデア発想を支援すべく, 商品の特徴の一つである 機能の組合せにより得られる新しい機能の希少さを評価するシステムを提案する。提案システムは, 新し い機能を表すフレーズを作成し，機能の希少さをWebの検索エンジンのヒット数を用いて評価し，希少と 評価された機能と，機能の元となった組合せを出力する。実験を行い，提案システムがアイデア発想を行 う被験者を支援できることを確認した。
\end{abstract}

キーワード : アイデア発想支援, 機能の希少さ, ウェブの検索エンジンのヒット数

\section{1. はじめに}

企業における新商品開発や, 研究所における研究開 発などの現場では, 新しい商品のアイデア, 新しい研 究のアイデアが日々考案されている. 特に, 新商品の 開発では，技術者だけでなく，消費者も加わり，一緒 になってアイデアを発想することもある $[1,2]$. アイ デア発想は思考の技術の一つであり $[3]$, 多くの人 が，アイデア発想に携わる世の中になっている.

1940 年代に Osborn によって発表されたブレイン ストーミング [4]を初めとして, 多数のアイデア発想 の方法が提案されてきている。アイデア発想方法は大 きく 4 つに分類することができ,「発散型」「収束型」 「統合型」，そして「態度技法」がある [5]。発散型の方 法とは, 多くのアイデアを発散的に出すための方法で あり, 収束型の方法とは, 出されたアイデアを収束的 にまとめていくための方法である。一般に, アイデア 発想に打いては, 発散状態と収束状態を繰り返すこと により，良いアイデアが練られて行く．統合型の方法 は, 発散型と収束型の双方を含むものであり, 態度技 法とは，アイデアを発想する人の態度をコントロール

$\dagger \quad$ An Idea Generation Support System Evaluating Function's Novelty in Product Combination

Yoko NISHIHARA, Junya HIBINO, Junichi FUKUMOTO and Ryosuke YAMANISHI

* 立命館大学情報理工学部

College of Information Science and Engineering, Ritsumeikan University
するための方法である，態度技法の例として，六色帽 子思考法 [6]がある。六色帽子思考法では，6つの思 考スタイルを 6 色の帽子により表現する。アイデアを 発想する人にそれぞれ異なる色の帽子を与え，アイデ ア発想の場に 6 種類の思考スタイルの人間を集め, ア イデア発想をコントロールする。態度技法は発散型, 収束型, 統合型の方法と組合せて使われる。

発散型の方法の一つとして, 既存の要素を組合せて 新しいアイデアを発想する方法がある。これを組合せ 発想と呼ぶ. Youngは, アイデアとは既存の要素の 新しい組合せ以外の何ものでもなく, 既存の要素をつ なぎ合わせる新たな関連性を見つけ出すことによっ て, アイデアを発想すると主張している[7]。この組 合せ発想を支援するシステムが提案されており $[8]$, アイデア発想に有用な組合せを絞りこめるようになっ てきた。しかし, 絞り込まれた全ての組合せが有用と いうわけではない。

新商品のアイデアを発想する際, 組合せ発想におい ては, 2 つ商品が持つ特徴や機能を組合せて, 新し い特徵や機能を作り，それを元として新商品を発想す ることが多い. 2000 年前後に発売され, 流行商品と なったカメラ付き携帯電話は, 組合せ発想により得ら れた商品の一つである. カメラ付き携帯電話は, 携帯 電話が持つ「メールを送る」という機能と, デジタルカ メラが持つ「写真を撮る」という機能が組合わされてで きた, 「写真を送る」という, その当時は希少な機能を 持った商品であった。この機能が, 女子高校生達の間 
で瞬く間に広がり，利用された結果，カメラ付き携带 電話は他の携帯電話を駆逐し，現在も多くの人に利用 されている，著者らは，組合せにより得られる機能の 希少さを評価することにより, 有効な組合せを厳選で きる可能性があると考えた。

そこで, 本研究では商品の機能の組合せにより得ら れる機能の希少さを評価することにより, 新商品のア イデア発想を支援するシステムを提案する。本研究で は多くのアイデアを発想する発散状態のフェーズを支 援する。提案システムを用いて出されたアイデアの中 から, 良いものに絞り込んで行く収束状態のフェーズ は対象としない 1 .

\section{2. アイデア発想支援に関する従来研究}

アイデア発想支援に関する従来研究を紹介し, 最後 に本研究の位置づけを示す.

\section{1 発散型, 収束型のアイデア発想方法}

アイデア発想では，多くのアイデアを発散的に発想 すること，得られたアイデアを収束的に統合していく

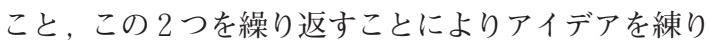
上げて行く，発散型と収束型のアイデア発想の代表的 な方法を紹介する。

発散型の代表的な方法に, ブレインストーミングが ある [4]。ブレインストーミングでは, 複数の人が集 まり，思いついたアイデアを次から次へと発言してい く、アイデアを聞いた人は，先のアイデアに同意する ことはできても，拒否することはできない，出された アイデアの良い所に着目し，他のアイデアと結びつけ たり, 改善したりして, より良いアイデアを数多く出 して行こうとする方法である。

アイデアを発想する際には, 事物の関連を見出すこ とが重要になる。マインドマップ $(\mathrm{R})$ は発散型のアイ デア発想方法の一つである [9]。中心なる事物に対 して, 関連する事物を結びつけた二次元の図を作成し ていくことにより，アイデアの発想を促す方法である.

アイデア発想の収束型の方法としては, KJ 法 $(\mathrm{R})$ [10]がある．KJ法では，1枚につき1つのアイデア やデータが記述された紙のカードを複数枚用意する.

関連するカードをまとめグループを作り，グループに タイトルをつける。その後，グループ間の関連を，矢 印を用いて表現し，考えをまとめることに用いる．KJ 法は, 本来は, 紙べースで行うものだが, 近年のデジ タルデバイスの発展と普及に伴い, 複数のタブレット

1 アイデア発想の発散状態と収束状態の繰り返しを支援するた めには, 提案システムに加えて新たな方法を提案する必要が ある。
端末を用いて作業空間を柔軟に拡張しながら行う方法 や[11]，紙とディジタルペンを用いたハイブリッド型 KJ法[12]なども提案されている.

\section{2 組合せ発想の支援}

組合せ発想は, 発散型のアイデア発想方法の一つと 考えられる，組合せ発想では, 既存の要素の特徵を組 合せ，新しいアイデアを発想する。どのような組合せ でも，新しいアイデアにつながるというわけではな い.アイデア発想に有用な組合せに絞り込むための方 法が必要である.

流行する商品となる可能性が高い組合せを評価する システムが提案されている[8]。このシステムは, 流

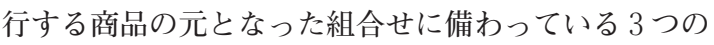
特徵を用いて， 3 つの特徴を満たす組合せを大量の組 合せの中から抽出する。 3 つの特徴とは (1) 組合せの 一方の商品が多くの人に認知されていること，(2)も う一方の商品に新規性があること，(3) 組合せが多く の人に注目されて打らず希少なこと，である。 システ ムが抽出した組合せを参照し，ユーザは新しいアイデ アを発想する。組合せ発想により発想されたアイデア を, ブラッシュアップして行くための会話方法なども 研究されている[13].

\section{3 本研究の位置づけ}

本研究では, アイデアの発想を支援するための発散 型の方法を提案する. 既存の商品が持つ機能を「(目的 語) (助詞十述語)」とフレーズにより表現し, 商品の機 能の組合せにより得られる新しい機能を, フレーズ内 の目的語を入れ替えることにより生成する。生成した 新しい機能を表すフレーズの希少さをWebの検索エ ンジンの検索ヒット数を用いて評価する。 これが提案 システムの新規性になる。提案システムの有用性を示 すために, 検索ヒット数を用いて評価された希少な機 能を提示することが，アイデア生成に与える効果を明 らかにする，加えて，既存の組合せ発想を支援するシ ステム $[8]$ と比較し, 提案システムの方がよりアイデ ア発想に与える効果が大きいことを示す。

\section{3. 希少な機能の提示による新商品のアイ デア発想支援システム}

初めに本研究のアプローチを説明する。本研究で は, 商品の機能の組合せにより得られる機能の希少さ を評価する。商品は大辞林にて「商取引されるもの. 財貨・サービスなど」と定義されている。本研究では 時計や携帯電話といった物理的な形を持つ物に加え, サービスといった物理的な形を持たない物も商品とし 


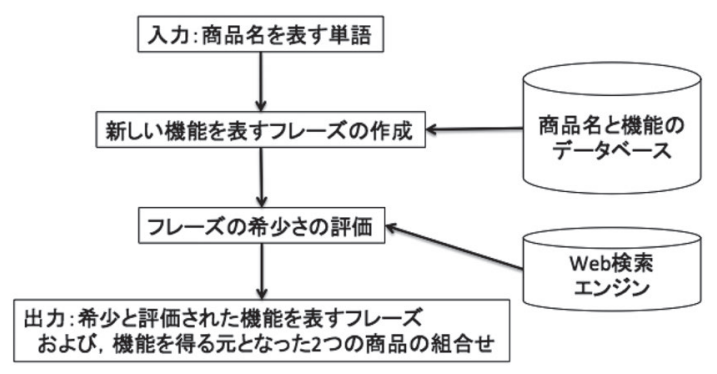

図 1 提案システムの処理の流れ

て，アイデア発想に用いる。得られる機能は，個々の 商品が持つ機能を元に作成されると考える. 元となる 機能を動詞と目的語からなるフレーズで表現し，フ レーズ内の目的語を入れ替えることにより，新しく得 られる機能を表現する。フレーズの希少さをもって， 表現された機能の希少さを評価する。希少な機能とそ れを持つ組合せを提示することにより，ユーザのアイ デア発想を支援する

図 1 に提案システムの処理の流れを示す。商品を組 合わせてアイデアを発想するため，2つの商品が必要 となる。組合せに用いる商品の 1 つはユーザが選択 し，もう1つは提案システムが組合せにより得られる 機能の希少さを評価することにより抽出される。ユー ザは組合せたい商品を選択し，商品名を表す単語を入 力する. 提案システムは, 商品名が記述されたデータ ベースにアクセスし, 入力された商品と組合せること によって新しく得られる機能のフレーズを作成する. 得られた機能の希少さを評価するために，Webの検 索エンジンを用いて, 機能のフレーズの検索ヒット数 を得る．検索ヒット数が [14]を参考に定めた閾值内に 存在すればフレーズが表す機能は希少と評価する。 ステムは，希少な機能とそれを持つ組合せをユーザに 提示する。ユーザは出力された情報をみて，機能を活 かし，組合せ発想により新商品のアイデアを発想す る。例えば，ユーザが「デジタルカメラ」を入力する と, 希少と評価された機能「写真を乾かす」と, それを 構成できる機能を持つ商品の一方である「洗潍乾燥機」 などが出力される.

\section{1 システムへの入カ：商品名を表す単語}

提案システムには，組合せて新商品のアイデアを発 想するために，商品名を表す単語を入力する．現時点 では, 商品名と商品の持つ機能が記述されたデータ ベース(表 1 )の中から選択する.
表 1 商品名と商品が持つ機能のデータベース (一部)。(商品名の記載として,「サービス エリア」は正しくは「サービスエリアで提 供されるサービス」,「カフェ」は「カフェ で提供されるサービス」となる.)

\begin{tabular}{|c|c|}
\hline 商品名 & 商品が持つ機能 \\
\hline ノート & $\begin{array}{l}\text { ノートに書き留める } \\
\text { アイデアを書き留める } \\
\text { 要点を書き留める }\end{array}$ \\
\hline プロジェクター & $\begin{array}{l}\text { 画像をスクリーンに投影する } \\
\text { 映像をスクリーンに投影する }\end{array}$ \\
\hline テレビ & テレビ番組をみる \\
\hline 地図 & 土地情報を調べる \\
\hline デジタルカメラ & $\begin{array}{l}\text { 写真を撮影する } \\
\text { 動画を撮影する }\end{array}$ \\
\hline スピーカ & $\begin{array}{l}\text { 音楽を聴く } \\
\text { 音声を聴く }\end{array}$ \\
\hline ミキサ & $\begin{array}{l}\text { 食材を砕く } \\
\text { 食材を混ぜる }\end{array}$ \\
\hline 洗米機 & 米を洗う \\
\hline 掃除機 & ゴミを吸引する \\
\hline 名刺入れ & 名刺を携帯する \\
\hline サービスエリア & $\begin{array}{l}\text { 高速道路で給油する } \\
\text { 高速道路で食事をする } \\
\text { 高速道路でモノを買う } \\
\text { 高速道路で用をたす }\end{array}$ \\
\hline カフェ & $\begin{array}{l}\text { コーヒーを飲む } \\
\text { 料理を食べる }\end{array}$ \\
\hline 血圧計 & 血圧を測定する \\
\hline 冷蔵庫 & 食料品を低温で保存する \\
\hline
\end{tabular}

3.2 商品名と商品が持つ機能が記述されたデータベー ス

提案するシステムでは, 商品の特徴の組合せにより 新しく得られる機能の希少さを評価する。新しい機能 は，元の商品が持つ機能を元にして作る，商品が持つ 機能を表すデータを, Webなどの半構造化されたデー タから自動的に取得することは困難である。そのた め, 商品名と商品が持つ機能をあらかじめ記述した データベースを用意し, 新しい機能を表すフレーズの 作成に用いる。

商品の機能は, 商品を主語として見た場合の機能で はなく，人を主語としてみた場合の機能とする。商品 のアイデアを考える際, 新しく得られる機能を人がど う用いるかを考慮する必要があるため, 人を主語とし た機能とした。提案システムでは, 著者の一人が商品 名を表す単語を大辞林と Wikipedia で調べた後, 商品 
を用いることによって人が達成可能なことを機能とし て表現した。 大辞林と Wikipediaに記載されていた語 義説明文から，機能を表す目的語と述語，それらをつ なぐ助詞を抜き出し，抜き出したものを元にして機能 を表現した。商品が持つ機能は, 人を主語として「(目 的語) (助詞+述語)」の形式で記述する。機能によって は目的語を 2 つ上とるものもある。その場合は，全 ての目的語を記述する。ただし, 助詞+述語は 1 つの みとする。データベースの一部を表 1 に示す。データ ベースには90 個の商品名, 162 件の機能 ( 1 個の商品 あたり平均 1.8 件の機能)がある。 2 個の商品で 1 つ の組合せができるため, $90 \times 89 \div 2=4005$ 通りの組合 せができる。商品 $\mathrm{A}$ と商品 $\mathrm{B}$ がそれぞれ $\mathrm{n}$ 個, $\mathrm{m}$ 個 ずつ機能を持っており, A と B が持つ機能に同じもの がない場合, A と B の組合せにより得られる機能の数 は $n m / 2$ 個となる。この積を, 任意の商品の組合せに 対して算出し, 積の和を算出すると機能の組合せの総 数は 10,848 個となる。

\section{3 商品の組合せにより得られる機能を表すフレーズ の作成}

入力された商品と組合せることにより新しく得られ る機能を, フレーズとして表現する。フレーズは $2 つ$ の商品が持つ機能を元にして作成する。フレーズにあ る目的語を相互に交換することにより, 新しい機能を 表すフレーズを得る。目的語が同じ場合は，交換して も新しいフレーズは得られないため, ここでは目的語 が異なる場合のみ新しい機能が得られるとする.

2 つの商品 $\mathrm{A}$ と B があり, それぞれの機能が以下 のように与えられているとする。

- 商品 $\mathrm{A}$ ：「(目的語 $\mathrm{A})($ 助詞 $\mathrm{A}+$ 述語 $\mathrm{A}) 」$

- 商品 $\mathrm{B}$ : 「(目的語 $\mathrm{B})($ 助詞 $\mathrm{B}+$ 述語 $\mathrm{B})\rfloor$

この $2 つ の$ 機能を表すフレーズの目的語を入れ替 え, 新しい機能を表すフレーズを作成する。即ち,

-「(目的語 $A)($ 助詞 $B+$ 述語 B)」

-「(目的語 $B)$ (助詞 $A+$ 述語 $A) 」$

と 2 つのレーズを作成する。例えば，パソコンの持 つ機能が「絵を描く」, 香料の持つ機能が「食品に香り をつける」として与えられている場合, 目的語を入れ 替えて,「絵に香りをつける」と「食品を描く」と, 新し いフレーズが 2 つ得られる。

\section{4 機能の希少さの評価}

機能が希少であれば，その機能を持つ商品は世の中 には余り存在せず，機能を表すフレーズが使用される 頻度も低いと考えられる. 即ち, 機能の希少さを評価 するためには, その機能を表すフレーズが世の中で使 用されている頻度を調べればよい。そこで，Webの 検索エンジンを用いて，フレーズが使用されている Web ページの数を調べ, 機能の希少さを評価する.

機能を表すフレーズをクエリとして, 検索エンジン に入力する。クリを与える際は，フレーズの両端を ダブルクォーテーションで囲い, 完全一致検索を行 う。これにより，フレーズそのものを含むWebぺー ジの件数を得る.

得られた検索ヒット数が少ないほど, フレーズが使 用されているWeb ページが少なく，フレーズが表す 機能は希少と評価できる。しかし, 検索ヒット数が少 なすぎると, 希少ではなく, あり得ない機能と見るこ

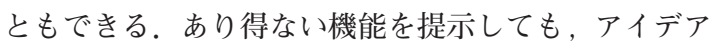
発想の支援にはつながりにくいと考えられるため, 適 切な範囲の検索ヒット数を持つ機能を提示する必要が ある。

そこで, 検索ヒット数の值によって, 検索キーワー ドをグループ分けしている事例 $[14,15]$ を参考にし， フレーズを 4 つのグループに分類する. 表 2 に示す 4 つのグループは, 検索ヒット数の多い順に, ビッグ, ミドル，スモール，ベリースモールとなる。このう ち, ビッグやミドルグループは検索ヒット数が高く, フレーズが多くのWeb ページで使用されているた め, 希少な機能とは考えない. ベリースモールグルー プは検索ヒット数が最も少ないが, 検索エンジンが保 持するWeb ページの全数に対して, 検索ヒット数が 少なすぎ，あり得ない機能と考える。本研究では，又 モールグループ, 即ち検索ヒット数が 11 件から100,000 件に属するフレーズの機能を, 希少な機能と評価し,

表 2 検索ヒット数により分類された機能を表 すフレーズのグループ

\begin{tabular}{|l|l|}
\hline グループ名 & グループの説明 \\
\hline ビッグ & 機能を表すフレーズの検索ヒッ \\
& ト数が $1,000,001$ 件以上のもの. \\
\hline ミドル & 検索ヒット数が 100,001 件から \\
& $1,000,000$ 件までのもの. \\
\hline スモール & 検索ヒット数が 11 件から \\
(希少な機能) & 100,000 件までのもの. \\
\hline ベリースモール & 検索ヒット数が 1 件から 10 件ま \\
& でのもの. \\
\hline
\end{tabular}


提案システムはスモールグループに属するフレーズの 機能を出力する。例えば「デジタルカメラ」に対して は，「洗濯乾燥機」との組合せにより得られる「写真を 乾かす」などが提案システムから出力される.

Webの検索エンジンのヒット数は, その仕様のた めに, 極めて短時間の間に, 不自然なほど検索ヒット 数が増減することがある $[16]$ 。さらに，一般的には希 少な機能であっても，Webで一部の人にシェアされ ることにより，一時的に検索ヒット数が高くなること がある。たまたま急降下，または急上昇した時の検索 ヒット数を機能の希少さの評価に用いると問題が生じ る. 提案システムを利用する上では, 検索ヒット数を 継続的に観察し，急降下または急上昇があった際の ヒット数を利用しないようにする必要がある。そのた め実験では, 用いた検索ヒット数 (2013 年12月 6 日か ら 2 週間で取得)に対して, 2015 年 3 月 6 日から 2 週 間で取得した検索ヒット数と比較し, 表 2 に示したグ ループが変わるほど検索ヒット数が変化したものはな かったことを確認した。

\section{5 システムからの出カ：希少な機能を表すフレー ズ，および組合せ可能な商品の集合}

提案システムは，ユーザが入力した商品に対して得 られる，スモールグループに属する希少な機能のフ レーズ，および組合せ可能な商品の集合を出力する. 例えば，「デジタルカメラ」に対しては，希少な機能を 表すフレーズの「写真を乾かす」と, 組合せ可能な商品 「洗濯乾燥機」が出力対象となる。提案システムのユー ザは，機能をイメージしながら，組合せ発想により新 商品のアイデアを発想する.

\section{4. 予備実験}

提案システムにより, 新商品のアイデア発想が支援 されるかどうかを評価する実験を行った。

\section{1 実験手順}

提案システムは「スモールグループ」に属する機能 と, それを構成する商品の組合せを出力する。提案シ ステムの有効性を評価するために，「ビッググループ」 「ミドルグループ」「ベリースモールグループ」に属する 機能と，元れを構成する商品の組合せを出力するシス テムを用意し，これを比較システムとした。予備実験 では, 提案システムと比較システムを比較することに より, 提案システムの有効性を評価した。 以下の手順 により実験を行った。

手順(1) 被験者は, 提案システムと比較システムが出
力した機能と組合せを参照し, 新商品のアイデア を発想する，発想したアイデアを文章で記述する。 手順(2) 別の被験者は, 発想されたアイデアの質を評 価する。質は，新規性，有用性，実現可能性の 3 点から評価する。

手順 (3) 実験者は, 発想されたアイデアの新規性, 有 用性，実現可能性の平均值を算出する。併せて， 3 つの評価値の積の平均値も算出する.

手順 (4) 実験者は, 提案システムと比較システムの間 で，評価值の平均を比較する。

手順(1)において, 提案システムは「スモールグルー プ」に属する機能と組合せを出力するとし, 比較シス テムは「ビッググループ」「ミドルグループ」「ベリース モールグループ」に属するものを出力するとした，実 験者は 4 つのグループに属する組合せを 3 つずつ選択 し，合計で 12 件の組合せと機能が記述されたシート を被験者に提示した。シートの例を表 3 に示す。組合 せを提示する際は, 検索ヒット数が降順や昇順になら ないように適宜入れ替えた。シートは 3 種類作成し た。機能の希少さを評価する際，Yahooの検索エンジ ンを用いて検索ヒット数を得た。検索ヒット数は 2013 年12月 6 日から 2 週間で取得した ${ }^{2}$.

商品のアイデアを発想した被験者は 15 名で，いず れも情報理工学部の大学生であった。実験者は被験者 に，提示された機能をイメージしながら，2つの商品 を組合せて得られる新商品のアイデアを発想し，アイ デアの説明をシート内に文章として記述する旨を依頼 した。説明を記述する字数に制限は設けなかった。ア イデア発想にかける時間は, 12 件の組合せに対して 合計で 30 分以上とした。発想されたアイデアは $12 \times$

表 3 予備実験に用いた機能と商品の組合せが記述さ れたシートの例

\begin{tabular}{|l|l|l|}
\hline 機能 & 商品 $\mathrm{A}$ & 商品 $\mathrm{B}$ \\
\hline 絵に香りをつける & パソコン & 香料 \\
食材を閲覧する & ミキサ & スマートフォン \\
食パンと遊ぶ & オーブントースタ & ロボット \\
ゴミを砕く & 掃除機 & ミキサ \\
食料品を貯蔵する & コンビニエンスストア & タンク \\
メールを作る & スマートフォン & ロボット \\
米をみる & 炊飯器 & テレビ \\
手首を洗う & 腕時計 & 洗米機 \\
インターネットを録画する & スマートフォン & レコーダ \\
無線通信を楽しむ & WiMAX & 音楽 \\
食材をとる & ミキサ & メモ帳 \\
\hline
\end{tabular}

2 ユーザの発想支援を素早く行うために, 検索ヒット数を常に 取得し,データベースに蓄えておくことで, より実用的なシス テムになると考えられる. 
15 名の合計 180 件であった ${ }^{3} .1$ つのシートに対して 5 名の被験者がアイデア発想に取り組んだ。

手順 (2)に扔いて, 発想されたアイデアを評価した 被験者は 3 名で, いずれも情報理工学部の大学生で あった。アイデアを発想した被験者と, 評価した被験 者は別人であった。各被験者は 180 件のアイデアに対 して, 被験者が記述した説明文を読み, アイデアの質 を評価した。質は, 新規性, 有用性, 実現可能性の 3 点で評価した。これはアイデアの評価において，既存 研究で頻繁に利用されている指標である[17]. 評価が 高ければ 4 点, 低ければ 0 点と， 5 段階で評価した。

手順（3）に打いて，実験者は新規性，有用性，実現 可能性に加えて, 3 つの評価值の積も平均をとった. 積をとることにより, 全ての条件が満たされた場合に 最も高い評価值を付与することができる．3つの評価 值の積が高いほど，各評価值が高いということにな り，アイデアを総合的に評価する際に利用しやすい． 平均を取る際は, グループごとにアイデアを分類し て,グループ内で平均を取った。

\section{2 実験結果}

発想された商品のアイデアの例を表 4 に示す．機能 と 2 つ商品の組合せが組み込まれたアイデアが発想 されていた. 15 名の被験者がアイデア発想に要した 時間の平均は 49 分であった。被験者は, 機能と商品の 組合せを見て，時間をかけてアイデアを発想したこと が, 平均所要時間より伺える。

評価者が評価した新規性, 有用性, 実現可能性, 3 つの評価值の積, それぞれの平均值を表 6 に示す. 3 名の被験者の評価の一致について, Kendall の一致係 数により算出した所, 0.54 から 0.65 の間にあり, 中 程度の評価の一致があった。新規性は, 比較のビッグ グループが最も低かった。それ以外の 3 つのグループ では大きな差はなかった，グループを要因とする一元 配置分散分析を行った所, 有意の差が見られた $(\mathrm{F}(3,521)$ $=3.39, \mathrm{p}=1.77 \times 10^{-2}$, 多重比較の有意水準は $\left.5 \%\right)$. 有用性は，又モールグループが最も高く，ビッググ ループが低かった.グループを要因とする一元配置分 散分析を行った所, 有意の差が見られた $(\mathrm{F}(3,521)=$ $9.49, \mathrm{p}=4.09 \times 10^{-6}$, 多重比較の有意水準は $\left.5 \%\right)$. 実現可能性は，グループ間で大きな差はなかった。3 つの評価值の積は, スモールグループが最も高く, ビッググループが最も低かった。グループを要因とす る一元配置分散分析を行った所，有意の差が見られた $\left(\mathrm{F}(3,521)=7.67, \mathrm{p}=5.06 \times 10^{-5}\right.$, 多重比較の有意水

3 このうち 1 件の組合せと機能が不適切であったため, 実験結 果からは外した。
準は $5 \%$ \%). 3 つの評価值の積が最も高かったことか ら，スモールグループに属する機能と組合せを用いる ことにより, 最も質の高いアイデアを発想できること が分かった，次の章で，実験結果を考察する．

表 4 発想されたアイデアの例

\begin{tabular}{|l|}
\hline システム \\
【グループ】 \\
・発想されたアイデア \\
(機能, 商品 $\mathrm{A}$, 商品 $\mathrm{B})$ \\
\hline 提案システム \\
【スモール】 \\
・パンにキャラクタの顔の焼き目をつけ, ロボット \\
はそのキャラクタの声で話しながら食べるように \\
促す \\
(食パンと遊ぶ, オーブントースタ, ロボット) \\
\hline 比較システム \\
【ビッグ】 \\
・スマートフォンで入カした内容をロボットに読み \\
取らせると, ロボットが手書きでメールを書いて \\
くれる \\
(メールを作る, スマートフォン, ロボット) \\
\hline 比較システム \\
【ミドル】 \\
・炊飯器にカメラを搭載して映し出す \\
(米をみる, 炊飯器, テレビ) \\
\hline 比較システム \\
【ベリースモール】 \\
・洗濯が終わると, パソコンにいれたデータ通り \\
に洗濯物を分けて拉いてくれる（母と父と私別や, \\
靴下とズボン別など） \\
(衣類を編集する, 洗濯機, パソコン) \\
\hline
\end{tabular}

表 5 新規性, 有用性, 実現可能性, 3 つの評価值の 積の平均。カッコ内は分散

\begin{tabular}{|l|r|r|r|r|}
\hline グループ & 新規性 & 有用性 & 実現可能性 & 3 つの積 \\
\hline 提案 : & & & & \\
スモール & 2.7 & 3.0 & 3.1 & 25.1 \\
& $(1.0)$ & $(1.0)$ & $(0.9)$ & $(150)$ \\
比較 : & & & & \\
ビッグ & 2.5 & 2.4 & 3.0 & 18 \\
& $(1.0)$ & $(1.2)$ & $(0.9)$ & $(124)$ \\
比較 : & & & & \\
ミドル & 2.8 & 2.6 & 3.0 & 20.0 \\
& $(0.9)$ & $(1.1)$ & $(0.8)$ & $(133)$ \\
比較 : & & & & \\
ベリースモール & 2.8 & 2.8 & 2.9 & 22.7 \\
& $(0.9)$ & $(1.0)$ & $(1.0)$ & $(153)$ \\
\hline
\end{tabular}


表 6 比較実験で用いた既存システムの出力

\begin{tabular}{|c|l|l|}
\hline 評価值順位 & 商品 $\mathrm{A}$ & 商品 $\mathrm{B}$ \\
\hline 1 & 体組成計 & 日食グラス \\
2 & Wi-fi & スピーカー \\
3 & サービスエリア & 体組成計 \\
4 & 体組成計 & ベビーカー \\
5 & モップ & 体組成計 \\
6 & 地図 & スピーカー \\
7 & 体組成計 & 距離計 \\
8 & 体組成計 & ファックス電話 \\
9 & 自転車 & 体組成計 \\
\hline
\end{tabular}

\section{5．考察}

新規性, 有用性, 実現可能性, および 3 つの評価值 の積について考察する.

\section{1 アイデアの新規性について}

アイデアの新規性は, ビッググループに属するもの が最も低く，それ以外の差はなかった。表 5 に記載さ れたビッググループのアイデアは，「スマートフォン」 と「ロボット」を組合せて，「メールを作る」という機能 を活かしたものであった。アイデアの内容は，「ス マートフォンで入力した内容をロボットに読み取らせ ると，ロボットが手書きでメールを書いてくれる」で あった。字を書くロボットは既に提案されている. 様々な場所で実現されている機能をべースとして，被 験者はアイデアを発想したことにより，既存の関係性 を多数想起し，新たな関係性を見出すことが難しく なったと考えられる。このため，アイデアの新規性が 低くなったと考えられる.

\section{2 アイデアの有用性について}

アイデアの有用性は，スモールグループに属するも のが最も高かった．表 5 に記載されたスモールグルー プのアイデアは,「オーブントースタ」と「ロボット」を 組合せて，「食パンと遊ぶ」という機能を活かしたもの であった。アイデアの内容は，「パンにキャラクタの 顔の焼き目をつけ，ロボットはそのキャラクタの声で 話しながら食べるように促す」であった。このような アイデアは例えば，朝の忙しい時間帯に，子供に急い で朝ご飯を食べさせないといけない母親には非常に有 用である，機能を表すフレーズがスモールグループに 属するので, この機能は希少と考えられる。しかし， 検索ヒット数が 0 ではないことから，フレーズが記述 されたWeb ページが存在しており，フレーズが表す
機能は現実世界に存在しうる可能性が高いと考えられ る. 希少であるが, 実現可能性の高い機能を活かした アイデアが発想されたので, アイデアの有用性が高く なったと考えられる。

反対に, アイデアの有用性が低かったのは, ビッグ グループとミドルグループであった。表 5 に記載され たミドルグループのアイデアは,「炊飯器」と「テレビ」 を組合せて，「米をみる」という機能を活かしたもので あった。アイデアの内容は,「炊飯器にカメラを搭載 して映し出す」であった。機能を表すフレーズがミド ルグループに属し，この機能は多くの場所で実現され ている可能性が高い. 従って, 組合せにより新商品と して提案しても，有用性が低いと評価されたと考えら れる.

アイデアの有用性という観点では，機能を表現する 際に用いられている動詞の多義性が関連している可能 性がある。「食パンと遊ぶ」に用いられている動詞「遊 ぶ」の語義は, 大辞林では 9 種類がある。複数の語義 を持つ動詞を持つフレーズが与えられると，ユーザの アイデア発想がその分だけ広がり, 有用なアイデアが 得られる可能性が高くなると考えられる. 提案システ ムは機能の希少さを検索ヒット数により評価するが, 動詞の多義性を評価することにより，有用なアイデア の獲得に繋がる可能性が考えられる.

\section{3 アイデアの実現可能性について}

アイデアの実現可能性は, グループ間で大きな差は なかった. 最高 4 点, 最低 0 点で評価をつけたので, 評価値の平均は 2 点となる。実現可能性の平均值は 2.9 から 3.1 の間にあった。このことから, 全てのグ ループから, 実現可能性の高いアイデアが得られたこ とになる，提示した機能を表すフレーズは，検索ヒッ 卜数が 0 件でなかったので, 実現できる可能性が高 い. それを活かしたアイデアであったため，実現可能 性が高いと評価されたと考えられる.

\subsection{3 つの評価値の積について}

3 つの評価值の積は，スモールグループに属するも のが最も高かった，反対にビッググループに属するも のが最も低かった。両者の違いは, 機能を表すフレー ズの希少さであった、スモールグループは希少な機 能, ビッググループはありふれた機能を意味する，希 少な機能を活かして商品を組合せてアイデアを発想し たため，スモールグループの総合的な評価が高くなっ たと考えられる。 


\section{6. 既存システムとの比較実験}

本章では, 2.2 節で紹介した既存研究 [8]の出力と提 案システムの出力を比較する実験を行い, 提案システ ムの有効性を示す. 提案システムは, 機能の組合せに より新商品のアイデア発想を支援するシステムであ る. 同じく組合せ発想を行う既存研究のシステムと比 較することにより, 組合せ発想を支援するシステムの 中で, 提案システムの特徴を明らかにすることができ ると考えられる.

\section{1 既存システムの説明}

既存システムは，2.2 節で紹介した条件を用いて組 合せを評価する。評価の前に, 組合せを構成する $2 つ$ の商品を, 認知度の高いもの (商品 $\mathrm{A})$, そうでないも の (商品B)に分ける。 その後, 以下に示す 4 つの指標 を用いて組合せを評価する。組合せ発想を行う時点を $\mathrm{t}$ 時点と仮定する.

指標 (1) 組合せる商品 $B$ の $t$ 時点での新規性 $(n o v(t))$ 指標 (2) $t-1$ 時点から $t$ 時点までの新規性の時間変化 $\left(\mathrm{ch} \_\right.$nov $\left.(\mathrm{t})\right)$

指標 (3) 組合せの $t$ 時点での斬新さ (ori $(\mathrm{t})$ )

指標 (4) $t-1$ 時点から $t$ 時点までの斬新さの時間変化 $\left(\mathrm{ch} \_\right.$ori $\left.(\mathrm{t})\right)$

指標 (1)の新規性は, $\mathrm{t}$ 時点での商品 $\mathrm{B}$ の検索ヒッ 卜数 (hit $(\mathrm{B}, \mathrm{t})$ とする)により評価する. 即ち,

$\operatorname{nov}(t)=\operatorname{hit}(B, t)$

を用いる。式(1)の值は低いほど良い。

指標 (2)の時間変化は, $\mathrm{t}-1$ 時点の新規性と $\mathrm{t}$ 時点 の新規性の差分により評価する。即ち，

ch_nov $(t)=\operatorname{nov}(t)-\operatorname{nov}(t-1)$

を用いる。式(2)の值は高いほど良い。

指標(3)の斬新さは，2つの商品の検索ヒット数 (hit $(\mathrm{A}, \mathrm{t}), \operatorname{hit}(\mathrm{B}, \mathrm{t})$ とする), 2 つの商品を空白で区切って, 1 つのクエリとしたときの検索ヒット数 (hit ( $\mathrm{A}$ and $\mathrm{B}, \mathrm{t}$ ）を用い, ヒット数の割合により評価する. 即ち,

$$
\operatorname{ori}(t)=\frac{\operatorname{hit}(\text { Aand } B, t)}{\operatorname{hit}(A) \operatorname{hit}(B)}
$$

を用いる。式(3)の值は低いほど良い。

指標 (4)の時間変化は, $t-1$ 時点の斬新さと, $t$ 時点 の斬新さの差分により評価する。即ち， ch_ori $(t)=$ ori $(t)-$ ori $(t-1)$

を用いる。式(4)の值は高いほど良い。

1 つの組合せに対して, 式(1) から式(4)と 4 種類の 評価值が付与される。それぞれの評価值は最大值, 最 小值が異なるので，同一に扱うことができない。そこ で, 評価の高い順に順位をふり，順位を新たな評価值 として付与する。最後に, 式(5)を用いて 4 種類の順 位の積をとり，積を組合せの有効性を示す評価値 value (A, B) として最終的に付与する.

$\operatorname{value}(A, B)=4$ つの評価值の順位の積

\section{2 既存システムと提案システムの比較実験の手順}

以下の手順により実験を行った。

手順 (1) 実験者は, 4 章の予備実験でスモールグルー プに属する機能と組合せを参照し, 発想された新 商品のアイデアをリストアップする.

手順 (2) 被験者は既存システムが出力する商品の組合 せを参照し，新商品のアイデアを発想する。

手順 (3) 別の被験者は, 手順(1) と (2)で発想されたア イデアの質を評価する。質は, 新規性, 有用性, 実現可能性の 3 点から評価する。

手順(4) 実験者は, 手順 (3)で評価されたアイデアの 質の平均值を算出する。併せて, 3 つの評価值の 積の平均值も算出する。

手順 (1)で，本実験では提案システムの出力を，4 章の予備実験で用いたものと同じで，機能を表すフ レーズがスモールグループに属した 9 個 ( 3 個の組合 せ $\times 3$ 枚のシート)の組合せとした。予備実験におい て発想された新商品のアイデア 45 個 $(9$ 個の組合せ $\times$ 5 名の被験者)を, 本実験でも用いた。

手順 (2)で, 既存システムの出力を得るために入力 した組合せは，提案システムのデータベースにある 90 個の商品から任意の 2 つを取り出し作成した組合せ, 即ち, $90 \times 89 \div 2=4005$ 個の組合せであった。認知 度の高い商品と, そうでない商品を分ける必要があっ たので, 初めに, 組合せを構成する商品をそれぞれク エリとして検索エンジンに入力し, 検索ヒット数を得 た. 検索ヒット数が高い方が, 認知度が高い商品とし た。既存システムでは, 商品の組合せを評価する際に 予めクロールした特定のテキストからなるコーパスに おけるヒット件数を用いて組合せを評価する。ここ で, 提案システムと既存システムで異なるコーパスを 用いると，実験結果が組合せの評価方法とコーパスの 
違いと $2 つ の$ 要因に依存することになり，実験結果の 考察が困難となる。実験結果がコーパスの違いに依存 する可能性を排除するために, 既存システムも検索エ ンジンをもちいてヒット件数を取得した。式(5)を用 いて，全ての組合せに評価值を付与した。 $\mathrm{t}-1$ は 2015 年 3 月 6 日から 1 週間, $\mathrm{t}$ は 2015 年 4 月 6 日から 1 週 間とした。評価值の高い上位 9 個の組合せを既存シス テムの出力として用いた。表 6 に, 既存システムの出 力を示す.

手順 (2)で, 新商品のアイデアを発想した被験者は, 5 名で, いずれも情報理工学部の大学生であった。実 験者は，2つの商品を組合せて得られる新商品のアイ デアを発想し，アイデアの説明を文章として記述する 旨を依頼した。説明を記述する字数に制限は設けず, アイデア発想にかける時間は 23 分以上とした ${ }^{4}$.

手順 (3)で, 発想されたアイデアを評価した被験者 は3 名で, いずれも情報理工学部の大学生であった. アイデアを発想した被験者と, 評価した被験者は別人 であった. 各被験者は, 提案システムから得られたア イデア 45 件と, 既存システムから得られたアイデア 45 件の合計 90 件のアイデアに対して, 被験者が記述 した説明文を読み，アイデアの質を評価した。 4 章 で, 提案システムから得られた 45 件のアイデアを評 価した被験者を本実験で用いることはできなかったた め，アイデアの質は再度評価してもらうこととした。 評価は, 新規性, 有効性, 実現可能性の 3 点を 5 段階 評価 ( 0 が最も低く, 4 が最も高い)で行った。手順 （4）は，4章の予備実験と同じ手順をとった.

\section{3 実験結果}

表 7 に, 提案システムと既存システムから得られた アイデアに対する, 新規性, 有用性, 実現可能性, 3 つの評価值の積の平均と分散を示す。 3 名の被験者の 評価の一致について, Kendallの一致係数により評価

表 7 提案システムと既存システムから得られたアイ デアに対する新規性, 有用性, 実現可能性, 3 つの評価値の積の平均. カッコ内は分散.

\begin{tabular}{|l|r|r|r|r|}
\hline システム & 新規性 & 有用性 & 実現可能性 & 3 つの積 \\
\hline 提案 & 2.9 & 3.0 & 3.1 & 22.6 \\
& $(0.53)$ & $(0.58)$ & $(0.56)$ & $(164)$ \\
\hline 既存 & 2.6 & 2.7 & 2.9 & 19.3 \\
& $(0.53)$ & $(0.33)$ & $(0.14)$ & $(51.9)$ \\
\hline
\end{tabular}

44 章の予備実験では 30 分 $\div 12$ 個のアイデア $=2.5$ 分 / 1 個の アイデアであったため, 9 個のアイデア $\times 2.5$ 分 $=22.5$ 分か ら 23 分とした。
した所，に対して Kendallの一致係数を算出した所， 0.48 から 0.63 の間にあり, 中程度の評価の一致があっ た. 提案システムと既存システムの新規性, 有用性, 実現可能性，3つの積の值を比較すると，いずれの值 も提案システムの方が高くなった (Welch の $\mathrm{t}$ 検定の 結果, 新規性 $: \mathrm{t}(267)=3.17, \mathrm{p}=1.69 \times 10^{-3}$, 有用 性 : $\mathrm{t}(253)=4.30, \mathrm{p}=2.43 \times 10^{-5}$, 実現可能性 $: \mathrm{t}(197)$ $=2.77, \mathrm{p}=6.09 \times 10^{-3}, 3$ つの積 $: \mathrm{t}(239)=6.20, \mathrm{p}=$ $\left.2.39 \times 10^{-9}\right)$ 。この結果から, 提案システムを用いる方 が，評価の高いアイデアを得ることが確認できた。

\section{7. おわりに}

本論文では, 商品の組合せから得られる希少な機能 を提示することにより, 新商品のアイデア発想を支援 するシステムを提案した。

提案したシステムは，2つの商品が持つ機能を用い て, 組合せから得られる機能を表すフレーズを作成 し, 機能の希少さをWebの検索エンジンの検索ヒッ 卜数を用いて評価する. 希少と評価された機能のフ レーズと組合せを出力し, ユーザのアイデア発想を支 援する。

予備実験の結果, 提案システムが出力する機能と組 合せが，ユーザのアイデア発想を最も支援できること が確認できた. 更に, 流行する商品の元となる可能性 が高い組合せを出力する既存システムと比較したとこ ろ, 質の高い組合せを得るには提案システムの方が優 れていることを確認し, 提案システムの有用性を確認 した.

今後の課題を述べる。提案システムは, 商品名や商 品を記述したデータベースを人手により作成したもの を用いたが，データベースを充実させることによっ て，ユーザのアイデア発想がより支援できると考えら れる. 今後は, データベースに追加する商品名, 商品 が持つ機能をWeb などから自動的に獲得できるよう にし, データベースの充実を図って行く。また, 提案 システムは, アイデア発想の発散状態に打いて, 機能 の希少さの評価を軸とした発想の支援を行う。アイデ ア発想の初めから終わりまでを支援するには, 発散状 態と収束状態の各状態に打いて, アイデアの新規性や 有用性，アイデアを受け入れる社会的な文脈など，他 の評価の軸も考慮する必要がある. 将来的には, 複数 の評価の軸を取り入れて, アイデア発想の各状態を支 援できるようにしていきたい. 検索ヒット数の母数は 年と共に増加するため, 検索ヒット数に関する文献を 利用して, 閾值を修正する必要があると考えられる。 2013 年に行った予備実験に扔いて, 2009 年の時点で のスモールグループに分類される検索ヒット数の機能 
が，最もアイデア発想に効果があることが分かった が，今後，提案システムを使って行く上では，閾值の 変化を考慮していく必要がある. 検索ヒット数の母数 の増大に依存しない評価指標の利用についても検討 し，提案システムをより使いやすいものへと改善して いく.

\section{参 考 文 献}

［1］「想定外」のヒットが続出 製品の価值は消費者がつ くる, 日経エレクトロニクス，944，pp.86-92, 日経 BP 社, 2007.

［2］和嶋雄一郎, 熟田祐一, 冨永直基, 植田一博, ユーザ 視点の導入による事業アイデアの質の向上,人工知能 学会論文誌, 28, 5, pp.409-419, 2013.

[ 3 ] Wallas, G., The Art of Thought, Harourt, Brace and Company, 1926.

[ 4 ] Osborn, Alex F., Applied Imagination, Scribner, 1979.

［5］宗森純, 由井薗隆也, 井上智雄, アイデア発想法と協 同作業支援，共立出版，2014.

[6] de Bono, Edward, Six Thinking Hats: An Essential Approach to Business Management, Little, Brown, \& Company, 1985.

[ 7 ] Young, James W., アイデアのつくり方, 阪急コミュ ニケーションズ, 1988.

[ 8 ] Nishihara, Y., Sunayama, W. and Yachida, M., Creative Activity Support by Discovering Effective Combinations, Systems and Computers in Japan, 38, 12 pp.99111, 2007.

［9］トニー・ブザン (著), バリー・ブザン (著), 神田昌 典(翻訳)，ザ・マインドマップ,ダイヤモンド社, 2005 .
[10］川喜田二郎, 発想法一創造性開発のために, 中公新書, 1967.

［11］爰川知宏, 前田裕二, 郷葉月, 伊藤淳子, 宗森純, Web ベース発想支援システム GUNGEN - SPIRAL II の複 数タブレット端末による拡張, 情報処理学会論文誌, 54, 2, pp.639-646, 2013.

［12］ 三浦元喜, 丹生隆寛, グループ発想支援システムにお ける拡張現実感技術の適用とその効果, 情報処理学会 論文誌，55，4，pp.1256-1263，2014.

[13] Nishihara, Y. and Ohsawa, Y., Communication Analysis focusing Negative Utterances in Combinatorial Thinking Games, The Review of Socionetwork Strategies, 4, 2, pp.31-46, 2010.

[14］永島穂波，はじめての SEO \& SEM - Yahoo!· Google 対策入門，秀和システム，2009.

[15］検索キーワードの探し方, http://www.daiko-kikaku. com/sem_key_word1.html（2014/1/27 アクセス）

[16］田野村忠温, 日本語研究の観点からのサーチエンジン の比較評価-Yahoo!と Googleの比較を中心に一, 計 量国語学, 26 (5), pp.147-157, 2008.

[17] Liikkanen, Lassi A., Hamalainen, Matti M., Haggman, Anders, Bjorklund, Tua, Koskinen, Mikko P., Quantitative Evaluation of the Effectiveness of Idea Generation in the Wild, Human Centered Design, 6776, pp.120129, 2011.

（2014年11月11日 受付）

(2015年 6 月 8 日 採録)

[問い合わせ先］

干525-8577 滋賀県草津市野路東1-1-1

立命館大学情報理工学部

西原陽子

E-mail : nisihara@fc.ritsumei.ac.jp 
介

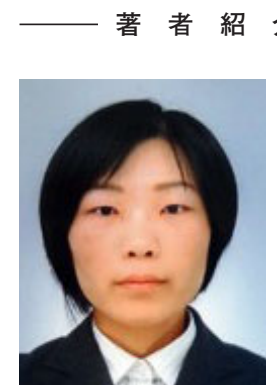

\section{皆原障量 [非会員]}

2003 年大阪大学基礎工学部卒業. 2005 年同大大学院基礎工学研究科博 士前期課程修了。 2007 年同研究科博 士後期課程修了。博士(工学)。日本学 術振興会特別研究員を経て，2008 年 東京大学大学院工学系研究科助教, 2009 年同講師, 2012 年立命館大学情 報理工学部准教授, 現在に至る。コ ミュニケーション支援，インタラク ション研究に興味を持つ. 情報処理学 会, 人工知能学会, 医療情報学会各会 員.

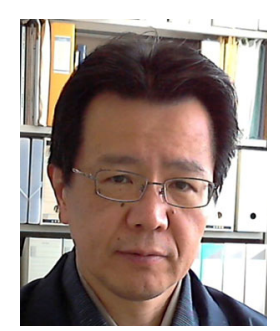

\section{福卆本流—俳会員]}

1984 年広島大学工学部第 2 類卒業. 1986 年同大学大学院工学研究科シス テム工学専攻博士前期課程修了。同 年, 沖電気工業(株) 入社. 1992-1994 年英国マンチェスター科学技術大学 Ph. Dコース在学. 2000 年立命館大学 理工学部情報学科助教授, 2004 年同 大学情報理工学部メディア情報学科助 教授, 2006 年同教授, 現在に至る. Ph.D. 談話構造解析, 質問応答技術, 情報抽出, 比喻表現理解などに興味を 持つ. 情報処理学会, 電子情報通信学 会, 人工知能学会, 言語処理学会, 観 光情報学会各会員.

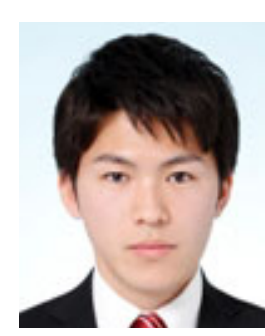

光比野 純也 [非会員]

2014 年立命館大学情報理工学部卒 業. 学士 (工学) 。

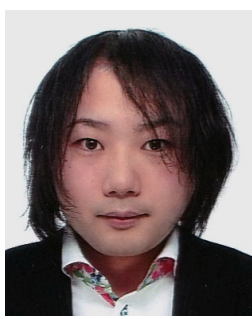

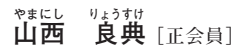

2007 年名古屋工業大学工学部知能 情報システム学科卒業. 2009 年同大 大学院工学研究科情報工学専攻博士前 期課程修了。 2012 年同博士後期課程 修了。同年, 立命館大学情報理工学部 助手, 2013 年同特任助教, 2014 年同 助教, 現在に至る。博士 (工学)。感性 情報処理, 音楽情報処理, ヒューマン インタラクションなどに興味を持つ。 情報処理学会, 人工知能学会, 日本感 性工学会各会員.

\section{An Idea Generation Support System Evaluating Function's Novelty in Product Combination by}

\section{Yoko NISHIHARA, Junya HIBINO, Junichi FUKUMOTO and Ryosuke YAMANISHI}

\section{Abstract :}

New products are frequently launched in the world. Most of new products could be regarded as combinations of characteristics of existing products. All the combinations do not always become seeds of new selling products. Each existing product has functions. A new function may be thought up by combining two functions of existing products. If a new function is novel, a combination may be a seed of a new selling product. This paper proposes an evaluation method of novelty of new functions obtained from product functions for supporting idea generation. The system makes phrases representing new functions, and evaluates whether each of new functions is novel or not using Web hit counts. The system outputs products combinations with novel functions. We conducted evaluation experiments, and verified that the proposed system can support participants in idea generation.

Keywords : Idea generation support, Function's novelty, Web hit counts

\section{Contact Address : Yoko NISHIHARA}

College of Information Science and Engineering, Ritsumeikan University

1-1-1, Noji-higashi, Kusatsu, Shiga, 525-8577, Japan

E-mail : nisihara@fc.ritsumei.ac.jp 